\title{
Construir desde el trauma. Representación y testimonio en La imagen perdida (2013) de Rithy Panh
}

\section{Building from trauma. Representation and testimony in The Missing Picture (2013) by Rithy Panh}

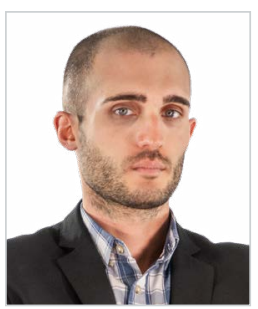

Álvaro Martín Sanz. Doctor en Investigación en Medios de Comunicación por la Universidad Carlos III de Madrid con premio extraordinario. Es además licenciado en filosofía por la Universidad de Salamanca y posee cinco masters relacionados con la cinematografía, la cultura contemporánea y la filosofía. Ha sido becario Culturex del Ministerio de Cultura en la Delegación Española Permanente ante la UNESCO y ha realizado estancias de investigación en las Universidades Sapienza de Roma y Sorbona de París. Especializado en cinematografía y estudios de la memoria, ha publicado una veintena de artículos en distintas revistas académicas como IC Journal, Confluencia o Kamchatka. Como cineasta, ha producido distintos cortometrajes y documentales que han sido seleccionados en más de cuatrocientos festivales y merecedores de más cincuenta premios.

Universidad de Valladolid, España

alvaro.martin.sanz@uva.es

ORCID: 0000-0002-8327-9830

Recibido: 27/06/2021 - Aceptado: 28/10/2021 - En edición: 03/12/2021 - Publicado: 01/01/2022

\section{Resumen:}

La imagen perdida (2013) de Rithy Panh es una de las obras de no ficción del cine contemporáneo más celebradas que tratan de reconstruir imágenes traumáticas del genocidio cometido por los Jemeres Rojos. El presente artículo realiza un análisis de la película desde la perspectiva de los estudios culturales sobre la memoria y el trauma utilizando para ello una metodología basada en el análisis textual. Nuestra hipótesis de investigación se basa en la idea de que la propuesta de no ficción que el cineasta sostiene en la obra no consiste tanto en buscar una imagen (o imágenes) ausente(s) del genocidio camboyano, tal y como indica su título, como de proponer una metodología adecuada para testimoniar el trauma personal que pueda ser aplicable a fenómenos similares. Para argumentar a favor de ello, se plantea un análisis sobre tres elementos: las representaciones de los perpetradores, la inclusión de la fantasía en el relato y, por último, la metafórica apología del testimonio por parte del creador. Más allá de verificarse la hipótesis, la conclusión principal que se extrae es que el testimonio surge como un deber y una necesidad ante actos traumáticos, pudiendo ser representado a través de diversas formas cinematográficas.

\section{Palabras Clave:}

Camboya; documental; trauma; memoria; representación.
Received: 27/06/2021 - Accepted: 28/10/2021 - Early access: 03/12/2021 - Published: 01/01/2022 Abstract:

The Missing Picture (2013) by Rithy Panh is one of the most celebrated non-fiction works in contemporary cinema that attempts to reconstruct traumatic images from the genocide committed by the Khmer Rouge regime. This article analyses the film from a cultural studies' perspective on memory and trauma using a methodology based on textual analysis. Our research hypothesis is based on the idea that Panh's non-fiction proposal in the film does not consist so much in searching for an absent image (or images) from the Cambodian genocide, as suggested by its title, as to propose an adequate methodology for witnessing personal trauma that may apply to similar phenomena. To argue in favour of this, we propose an analysis based on three elements: the representations of the perpetrators, the inclusion offantasy in the film's narrative, and, finally, the creator's metaphorical apology of the testimony. Beyond verifying the hypothesis, the main conclusion is that the testimony arises as a duty and a necessity in the face of traumatic acts, which can be represented through various cinematographic forms.

\section{Keywords:}

Cambodia; documentary film; trauma; memory; representation.

Cómo citar este artículo:

Martín Sanz, A. (2022). Construir desde el trauma. Representación y testimonio en La imagen perdida (2013) de Rithy Panh. Doxa Comunicación, 34, pp. 121-138.

https://doi.org/10.31921/doxacom.n34a927 


\section{Introducción}

La imagen perdida se convierte en 2014 en la película de la historia de Camboya que recibe una nominación al Óscar, en la categoría de Mejor Película de Habla No Inglesa. Antes de ello, el film fue estrenado en la sección Un Certain Regard de la $66^{\circ}$ Edición del Festival de Cannes, en donde lograría alzarse con el principal premio. Más allá de ello, la película realizó un amplio recorrido por festivales y certámenes de todo el mundo: Adelaida, Chicago, Jerusalén, Londres, Turín o Gante entre otros. Es por todo esto que podemos aseverar que La imagen perdida es la obra más célebre dentro de una filmografía en la que el cineasta camboyano Rithy Panh ha explorado distintos géneros y formas cinematográficas con el fin de indagar en la reconstrucción de la memoria colectiva de una sociedad como primera etapa desde la que elaborar un principio de justicia que pase ante todo por el reconocimiento a las víctimas de la catástrofe y por la señalización de los culpables (Martín Sanz, 2018: 213). El realizador ha dedicado su carrera a construir diversas películas que indagan en las raíces del genocidio para perpetuarlo en la pantalla y que así no caiga nunca en el olvido, enfrentándose así a la "máquina de borrado de memoria" del régimen revolucionario (Couteau, 2000: 20). Sus films pueden entenderse como un tejido colectivo de distintos personajes que busca desvelar, en una cuidadosa fragmentación temática que indaga desde las huellas del presente, los remanentes del terror de la Kampuchea Democrática de Pol Pot y sus Jemeres Rojos.

A modo de introducción biográfica, después de perder a su familia, un joven Rithy Panh logra exiliarse como refugiado político en Francia. Será en París en donde se forme como cineasta en el Institut des Hautes Études Cinématographiques (IDHEC) ${ }^{1}$. Después de graduarse, el creador vuelve a su país natal para crear toda una serie de aproximaciones, tanto de ficción como de no ficción, al genocidio acontecido, en el que se estima que desaparece aproximadamente el 25\% de la población camboyana (Margolin, 1997: 816-900). La falta de imágenes de archivo de la catástrofe lleva al cineasta a enfrentarse tanto a la ausencia de representaciones que prueben la barbarie, corroborando así el testimonio de los supervivientes, como a las imágenes propagandísticas que venden las virtudes del régimen derrocado. Es debido a estas circunstancias, que su cine se inserta en esta búsqueda del restablecimiento de la verdad, creando una suerte de contramemoria del evento genocida (Rollet, 2011:216) de tal forma que sus obras pueden ser vistas como rituales de duelo. El cineasta

busca restablecer la verdad, analizar el genocidio camboyano, luchar contra el borrado, dar vida, actúa también como un ritual de duelo, para sí mismo y para la sociedad camboyana en su conjunto, buscando evitar que los supervivientes se hundan en la locura perseguida por sus espectros (Lefeuvre-Déotte, 2016: 7).

O en palabras del propio realizador: "He venido al cine para salvarme, ni siquiera es la forma de expresarme; es morir o hacer esta película [sobre el S-21]”. (Panh en Tavernier, 2002). Además de esta función de testimonio personal, la función clarificadora y hasta pedagógica de la historia que poseen sus narrativas provoca que sus películas constituyan un nuevo imaginario colectivo de figuras de la memoria (Assman, 1995: 129) -basado en ideas, imágenes y representaciones varias- para la generación de la posmemoria, concepto que "describe la relación de la "generación de después" con el trauma personal, colectivo y cultural de la generación anterior, es decir, su relación con las experiencias que 'recuerdan' a través de los relatos, imágenes y comportamientos en medio de los que crecieron" (Hirsch, 2012: 19). Así, las representaciones que crea Panh suplantan la ausencia de las imá-

1 Reorganizado entre los años 1986 y 1988, el instituto es finalmente renombrado como la escuela La Fémis. 
genes que no existen (Martín Sanz, 2018b: 187). El cineasta se une así a toda una generación de realizadores que usan distintos recursos cinematográficos para crear un espectro memorístico más intenso que el del relato oral a través de estrategias que unen acciones teatrales, discursos y vestigios físicos del pasado (Ferrer y Sánchez-Biosca, 2019: 49).

Se forma un cine de difícil elaboración que, como un puzzle, va buscando las distintas piezas que perviven en la actualidad para intentar encajarlas en torno a una historia que sea comúnmente aceptada. Esa aceptación parece convertirse en el primer postulado ético que Panh va a fijar en su método de trabajo, que lejos de querer buscar soluciones generales a grandes preguntas o fijar la cronología de los sucesos con el máximo detalle posible, tal y como Claude Lanzmann plantea en Shoah, va a aferrarse a los relatos de la memoria de los testigos, supervivientes (por medio de la grabación de su testimonio) o no (a través de los documentos que estos han dejado atrás). Sin embargo, cabe remarcar que a la hora de crear los distintos relatos que trazan sus obras, lejos de la estrategia testimonial empleada por el citado cineasta francés, Panh se va a posicionar del lado de la imagen, haciendo uso de todos los materiales de archivo que puede rescatar del olvido:

En mi despacho de Phnom Penh, los armarios metálicos forman un muro. Contienen cartas, cuadernos, grabaciones de sonido, archivos, estadísticas demoledoras y mapas. Al lado, un local climatizado contiene los discos duros: las fotos, las grabaciones radiofónicas, los films de propaganda de los Jemeres Rojos y las declaraciones ante el tribunal penal. Todo el drama camboyano está ahí (Panh y Bataille, 2013: 18).

De esta forma, Panh rechaza la noción expuesta por Claude Lanzmann de que las imágenes pueden simplificar un evento que las excede y por ello debieran ser destruidas (Lanzmann 2011, 466). Panh se posiciona del lado de Jean-Luc Godard (Bonnaud y Viviant 1998) y de Didi-Huberman, quien a raíz de una exposición en la que se exhiben cuatro célebres imágenes tomadas por un miembro del Sonderkommando en Auschwitz realiza un artículo en el que defiende la salvaguarda de cualquier tipo de representación:

Afirmar, contra las tesis de lo inimaginable, que hay imágenes de la Shoah, no significa pretender que "todo lo real es soluble en lo visible" y que todo el crimen nazi está en cuatro imágenes fotográficas. Es descubrir, simplemente, que podemos pasar por estas cuatro imágenes para enfocar con un poco más de precisión lo que fue una realidad en Auschwitz, en agosto de 1944 (DidiHuberman, 2004, 170).

En el caso de Rithy Panh, esta utilización de los materiales de archivo supervivientes -que es recurrente en su filmografía- puede explicarse por las circunstancias de desaparición de muchas pruebas del genocidio. A pesar de que consideremos el cine como un arte perecedero que tiende hacia la desaparición de sus obras, tal y como puntualiza Soko Phay, la labor de destrucción de los Jemeres Rojos es la principal responsable de que de cerca de cuatrocientos films producidos en Camboya de 1960 a 1975 hoy no queden más que una treintena en mal estado (Phay, 2017: 149). Otro ejemplo significativo se haya en el hecho de que de la toma de la ciudad de Phnom Penh por el ejército revolucionario el 17 de abril de 1975 únicamente han sobrevivido unas pocas imágenes tomadas por el fotógrafo francés Roland Neveu (Ly, 2017: 169).

Así, va desarrollando el director camboyano toda una cinematografía que, aunque no varía en su principal método de aproximación, evoluciona en sus características y aproximaciones al sujeto, que es el principal centro de interés de su cine. Presenta diferentes representaciones que, lejos de sustituirse, muestran diversas técnicas complementarias que retratan a su manera variados puntos de vista sobre el periodo de la Camboya de los Jemeres Rojos. Un método de trabajo que aúna las escasas imágenes 
supervivientes con la palabra de los supervivientes, víctimas y verdugos. Esta aproximación, que más allá de pretender realizar una radiografía completa de las causas y factores que propiciaron el fenómeno genocida, busca adentrarse en las secuelas de este a través del testimonio de los supervivientes. Sobre esto cabe indicar que han sido la confrontación entre los unos y los otros, así como el concepto difuminado de los límites entre la ficción y el documental de algunas de sus obras, las nociones que le han llevado a ser acusado de cierta ambigüedad ética en lo relativo al trato de algunas situaciones (Hamilton, 2013: 185). Crítica que viene motivada por una aproximación a la figura del verdugo en la que, lejos de emitirse un juicio condenatorio, se busca la comprensión de los postulados ideológicos de la persona. Valga como ejemplo el tratamiento cercano de la entrevista que mantiene con el antiguo líder Duch en la tercera película de su trilogía sobre el S-21.

La imagen perdida (L'image manquante en el original) se cuestiona sobre la inexistencia de imágenes genocidas desde su mismo título, "la falta indica una necesidad o deficiencia sentida: se refiere a algo que debería estar ahí pero no está" (LaCapra, 2005: 74). Ante esta ausencia de imágenes traumáticas que no existen, Panh se va a encargar de recrearlas mediante unas figuras de arcilla que remiten a aquellas que moldeaba en su infancia (Torchin, 2014: 37). De esta forma, se configura un relato que, con un formato de poema que reverbera en la creación lírica del también superviviente Jean Cayrol en Noche y niebla (1956) de Alain Resnais, ofrece en primera persona una poetización del testimonio del creador: "La narración tiene a un yo como eje central: el propio Rithy Panh" (Zylberman, 2015: 119). En palabras de Bataille, co-escritor del guión:

Sus indicaciones eran más bien las de un director: "Más poético", "más oscuro"... Debían ser un poco como consignas poéticas. Deduje que habría una voz en off, pero no sabía quién hablaría. Todo era alusivo (Bataille en Ekchajzer, 2013).

Así pues, partiendo de una poetización del testimonio propio, La imagen perdida desarrolla un discurso cronológico sobre la memoria individual en el marco de las circunstancias genocidas. Ante todo, el propósito de Panh es la generación de esas imágenes que no existen más que en su recuerdo. Es por lo tanto la memoria la que genera el postulado ético en torno a la veracidad de las representaciones, que son también aceptadas por los demás supervivientes. "La imagen perdida opera un cambio de registro hacia la intimidad de la experiencia, el eco y las reminiscencias de todas estas imágenes y actos de la memoria que persisten." (Sánchez-Biosca, 2018: 2). En este sentido, la obra de Panh ofrece una prolongación cinematográfica de los lienzos del pintor Vann Nath, -protagonista de su célebre trilogía sobre el S-21-, los cuales se alzan como una búsqueda de justicia en un periodo de impunidad para muchos dirigentes revolucionarios (Nath, 1998: 188).

El presente artículo busca realizar un análisis del film desde la perspectiva de los estudios culturales sobre la memoria y el trauma utilizando para ello una metodología basada en el análisis textual que realiza una hermenéutica de las imágenes de la película. El estudio por lo tanto trata de desentrañar la iconografía de las imágenes del trauma que están presentes en la obra. Nuestra hipótesis de investigación se basa en la idea de que la propuesta de no ficción que dibuja Rithy Panh no consiste tanto en buscar una imagen (o imágenes) ausente(s) del genocidio camboyano, tal y como indica su título, como de proponer una metodología adecuada para testimoniar el trauma personal que pueda ser aplicable a más fenómenos traumáticos. Para argumentar a favor de esta idea se plantea un estudio sobre tres elementos: las representaciones de los perpetradores, la inclusión de la fantasía en el relato y, por último, la metafórica apología del testimonio por parte del creador. Así pues, de cara a realizar este análisis, se han seleccionado ocho escenas, las cuales se consideran las más representativas del film en cuanto a la formulación de estos tres elementos. Si bien estas secuencias en su conjunto no suponen más del $30 \%$ del metraje -debido principalmente a la brevedad 
de algunas de ellas-, la explicitud de su mensaje a través de la voz en off, o de las imágenes que contienen, provoca que sean de vital importancia para el objeto de este estudio.

\section{Contra las imágenes de los perpetradores}

Dentro de la tipología de imágenes del trauma podemos establecer, siguiendo a Sánchez-Biosca (2015: 5-6), una división conformada por cuatro tipos de imágenes: en primer lugar estarían las imágenes tomadas por los perpetradores, capturadas con el fin de identificar a sus enemigos con el objetivo ulterior de destruirlos. El segundo tipo de imágenes serían las tomadas por los liberadores con el objeto de desacreditar al régimen que viene de ser derrocado al mostrar retazos de la tragedia cometida. Como ejemplo puede pensarse en las fotografías realizadas por el ejército ruso en la liberación de Auschwitz o en las de las tropas vietnamitas al entrar en la Camboya de los Jemeres Rojos. El tercer grupo estaría formado por imágenes-pruebas tomadas por periodistas o cineastas que, motivados por una defensa de los derechos del hombre, tratan con sus imágenes de crear una denuncia ante la comunidad internacional. Este tipo de imágenes supervivientes se ven por lo tanto en la tesitura de tener que cumplir los estándares de la evidencia criminal (Winston, 2012: 98-99). Por último, estarían todas las imágenes-creación realizadas por las víctimas a posteriori que tratan de reconstituir las escenas que han vivido, tal y como es el caso de las imágenes que crea Panh.

La imagen perdida es un alegato testimonial que surge contra la primera tipología de imágenes, aquellas tomadas por los propios perpetradores. Esta problemática se ejemplifica de forma explícita cerca de la mitad del metraje. Panh muestra una recreación nocturna de un campo de ejecuciones (Killing field), presumiblemente el de Choeung Ek, pues era allí donde se exterminaba a la mayoría de los presos de la Tuol Sleng (S-21) (Williams, 2004). Estas imágenes buscan completar el vacío del material del material de archivo filmado por los vietnamitas en la liberación del centro de detención al incluir a verdugos y a víctimas. Trata Panh de construir una representación de una serie de imágenes que faltan, las fotografías tomadas por los Jemeres Rojos a los condenados segundos antes de su ejecución. Recrea para ello una escena en la que un figurín apunta su cámara hacia la víctima, de rodillas en el suelo y con los ojos vendados. Acompaña estas imágenes con un lírico testimonio en el que expone su pensamiento sobre la divulgación de las imágenes de perpetradores:

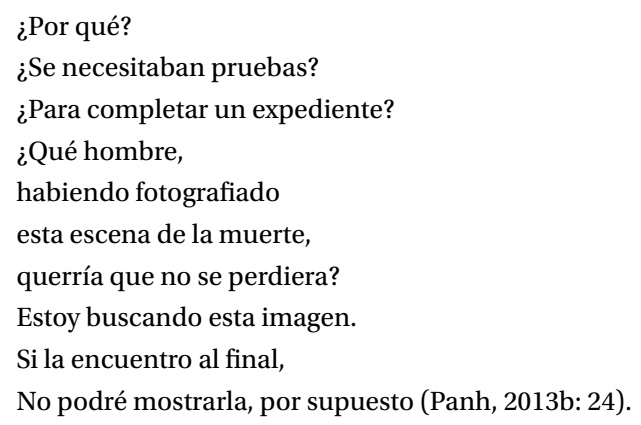


Imágenes de la muerte creadas para testificar la brutalidad. Lejos de querer borrar o esconder el crimen, la esencia de su existencia es dar prueba de que este ha sido cometido. Se recupera así el planteamiento de mostrar el momento de la ejecución que ya estaba presente en su célebre obra sobre el S-21. Se abre a su vez una cierta relación de voyeurismo entre el fotógrafo y el espectador que puede tornarse rápidamente en cómplice al ser atraído por el material. Siguiendo a Sontag: "En cuanto objetos de contemplación las imágenes de lo atroz pueden satisfacer algunas necesidades distintas. Fortalecernos contra las flaquezas. Volvernos más insensibles. Reconocer la existencia de lo irremediable" (Sontag, 2010: 85). En línea con lo señalado antes por Lanzmann, Panh rechaza su posible divulgación, sin embargo, con la distancia de la puesta en escena de sus figuras recupera el momento de la creación de estas, imagen perdida a su vez. Con una duración de plano más breve que las anteriores, la cámara realiza un rápido paneo que va desde otro individuo armado con una cámara fotográfica hasta la escena de ejecución, la cual tiene lugar en ese preciso instante congelado. Un jemer rojo se dispone a degollar a su víctima (fig.1). A pesar de la oscuridad de la toma, iluminada con tonos azulados para simular la noche, un brillante punto rojo, como impuesto desde fuera, reluce en el machete de arcilla simulando la sangre que está por derramarse en esta escena de pesadilla.

Figura 1. Un jemer rojo se dispone a degollar a su víctima

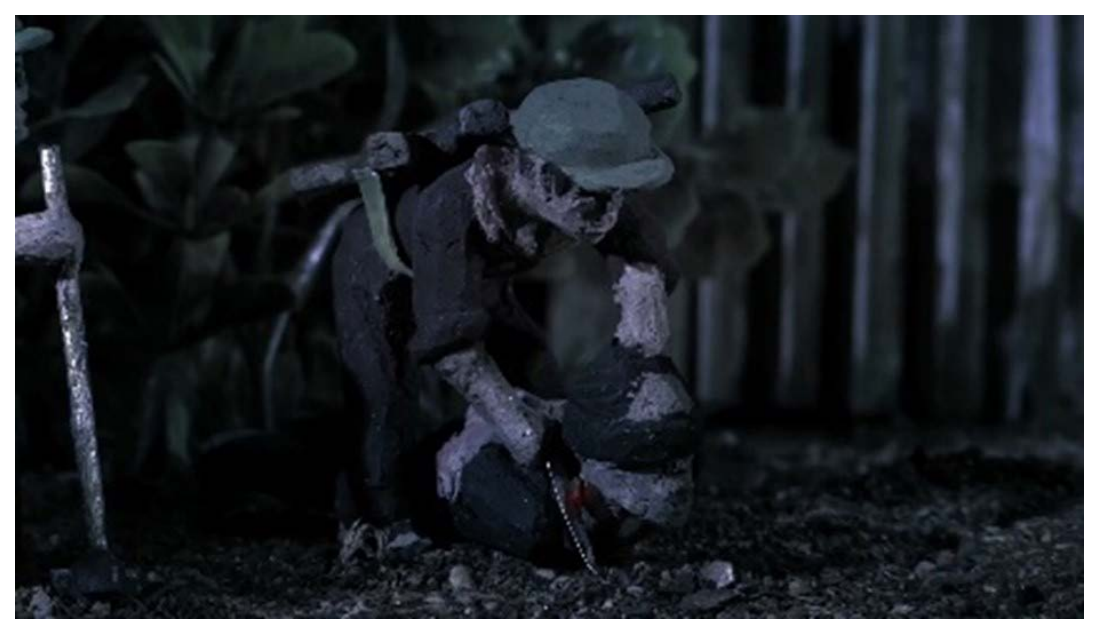

Fuente: fotograma La imagen perdida

Frente al anonimato de una representación que no aporta más que la brutalidad humana, Panh remite a las víctimas. Así, a continuación, el cineasta muestra otro tipo de imágenes tomadas por los perpetradores. Una grabación actual realiza un paneo por una exposición instalada de forma permanente desde el año 1979 en la prisión de Tuol Sleng, compuesta esta por cientos de imágenes tomadas por los Jemeres Rojos a sus víctimas (Caswell, 2014: 4). Este enorme archivo de fotografías, que se hacían cuando los detenidos llegaban a la prisión, provoca aún hoy muchas incógnitas en torno a su función. Se desconoce así el propósito de fotografiar víctimas de las que ya se sabía su posterior ejecución (Sánchez-Biosca, 2015: 155). El movimiento de cámara de Panh, termina efectuando un zoom sobre una fotografía, la correspondiente a Bophana. Joven cuya trágica historia, tal y como admite 
el creador (Panh, 2009: 169), descubre en la obra Les larmes du Cambodge (Élisabeth Becker, 1988). A raíz de ahí, realiza uno de sus primeros films célebres dentro del ámbito de la no-ficción, Bophana, una tragedia camboyana (Bophana, une tragédie cambodgienne, 1996), en el cual investiga en torno al asesinato de esta mujer y de su pareja. Panh deja la incógnita de la joven y el metraje avanza al material propagandístico filmado por los Jemeres Rojos en los campos de trabajo. Imágenes filmadas con una cierta distancia que permita observar la magnitud del trabajo colectivo.

Los planos generales de la propaganda, de trabajadores realizando distintas tareas en la construcción del nuevo régimen, son contestados a lo largo de la película por medio de la voz en off. De esta forma, la narración profundiza en los detalles que no permite contemplar la imagen de archivo. Panh realiza así con las palabras nueva aproximación a los sujetos filmados:

Veo las películas de propaganda

de los jemeres rojos,

estos niños que cargan.

Sus manos. Sus caras. Sus cuerpos

cansados.

Esta joven vanguardia está trabajando

para su propia destrucción (Panh, 2013b: 25).

El cineasta decide intervenir más adelante en la imagen de archivo propagandística al sobreponer en primer plano una figura de un cámara jemer rojo que filma la escena. Realiza esta figura un movimiento de rotación que da la vuelta al archivo y filma hacia el espectador, apuntando su objetivo fuera de campo. A pesar de la realidad de las imágenes del archivo, el cineasta recuerda que la imagen cinematográfica no es neutral, y que, lejos de serlo, puede verse convertida en un instrumento de destrucción o de fantasía (Torchin, 2014: 38). O en palabras del realizador: "Un film jemer rojo es siempre un eslógan" (Panh, 2013b: 34). En consonancia con esto, más adelante la edición presenta una serie de imágenes de archivo que no tienen nada que ver con aquellas que buscan elogiar al nuevo Estado. Peor conservadas estas, con encuadres menos elaborados y con una mayor proximidad a los sujetos que aparecen, a los que se graba desde su misma altura, se intuye una cierta sensación de filmación clandestina. Similar a cuando Panh graba a sus figurines detrás de elementos como ramas o vegetación, en primer plano. De igual modo, la crudeza de las imágenes tampoco tiene que ver con las previas. Montañas de barro en un entorno caótico con trabajadores que ya no se mueven rápidamente, al contrario, el cansancio aparece como un rasgo fundamental de estas escenas.

A pesar de filmar la generalidad, las imágenes no se centran en el acto del trabajo, sino en los sujetos. La cámara va más allá de filmar las propias acciones de trabajo para capturar el cansancio de los protagonistas. Así, una toma posterior muestra las penurias de un grupo de trabajadores para picar la tierra con la azada. Al lado de estos, otros cuantos guardan reposo en una posición estática. Estas imágenes se alejan de la energía y el vigor que recogían las filmaciones propagandísticas. Panh identifica finalmente la fuente:

El que ha filmado estas imágenes

lentas y verdaderas

se llama Ang Sarun.

Era un cámara jemer rojo (Panh, 2013b: 53). 
El cámara es representado de nuevo en la secuencia siguiente, en la que se recupera la figura de arcilla. De fondo, planos de un congreso de Pol Pot, y en primer plano, al igual que antes, la figura armada con la cámara que gira buscando inmortalizar eso que está más allá del registro oficial. El archivo que se expone, tal y como indica Panh, está compuesto por imágenes que son veladas parcialmente. Panh se pregunta los motivos de estas propiedades en la imagen, ¿error técnico o censura del cineasta? Lo cierto es que el desenlace del personaje, torturado y asesinado, parece responder a la pregunta.

Ang Sarum logra, con los medios del cine, significar que algo es disfuncional en lo que él da para ver. Filma lo que le pidió su patrocinador, pero logra poner en crisis las formas visuales para sacar lo real del orden establecido. Al destilar así un ligero disturbio, produce en los líderes tal ansiedad que pone su vida en peligro (Renard, 2018: 77).

Como un fantasma, la edición funde la figura con el fondo provocando una disolución en la nada de la misma. El personaje desaparece, pero no su película. Es a él a quien la película debe la existencia de ciertas imágenes del trauma que bien pudieran estar ausentes hoy día. Con La imagen perdida, Panh parece querer ir más allá de estas imágenes propagandísticas, tratando de continuar la misión emprendida por Ang Sarum. De esta forma, las imágenes propagandísticas que muestran el trabajo colectivo en planos generales que magnifican la coordinación de la nueva sociedad, son respondidas con comentarios críticos de la voz en off, así como con aproximaciones de Panh a sus figurines. Frente a la distancia fijada por la propaganda, que oculta el sufrimiento y la explotación, Panh combina toda una serie de primeros planos a sus traumatizadas figuras, creando así representaciones que responden directamente al archivo profundizando en los detalles que no se ven.

Figura 2. La ficción documenta la realidad

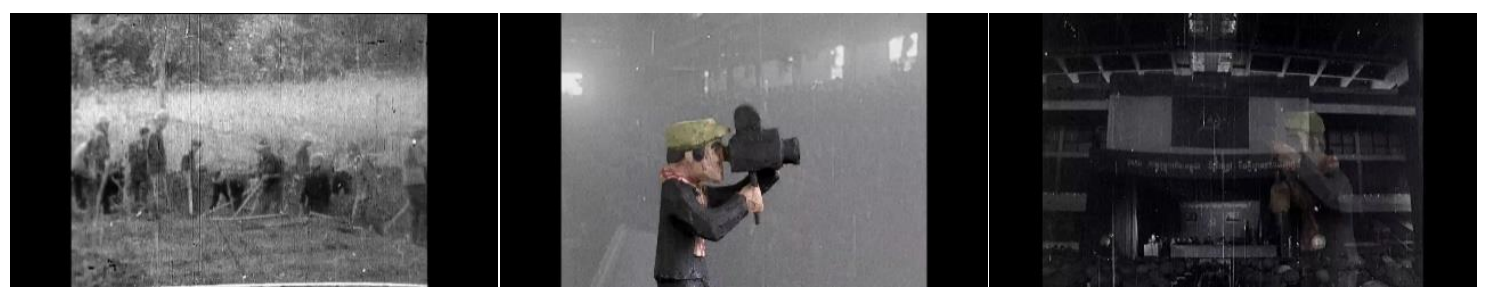

Fuente: fotogramas de La imagen perdida

\section{Construir desde la fantasía}

La propuesta del cineasta va desarrollándose como un testimonio directo en el que expresa lo vivido por medio de su inserción como figura de joven Panh dentro de los dioramas. Sin embargo, a medida que aumenta la crudeza del relato de su etapa en un campo de trabajo, el cineasta decide recurrir a la ficción reinterpretando así el pasado desde la óptica presente. Estas fantasías que se insertan en las distintas representaciones codifican el pensamiento infantil del momento además de ofrecer cierto respiro a la carga traumática del testimonio. Así pues, como ejemplo del primer uso, Panh muestra un diorama que representa una sesión de reeducación que se divide en distintos planos mientras la narración toma la voz del jemer rojo que se está dirigiendo al resto del grupo para hablar de promesas del futuro y de las bondades de la nueva sociedad. La fidedigna representación, que entre otros detalles presenta a oyentes desconcertados y hasta enfadados, es invadida por la fantasía. Fantasía del discurso que es 
puesta al mismo nivel que la realidad que los prisioneros están viviendo. Así, cuando la voz afirma que "Les hommes âgés seront nourris par une machine", Panh inserta en el diorama una máquina que recuerda a aquella que presentaba Chaplin en Tiempos Modernos (Modern Times, 1936) (fig. 3). El pensamiento del cineasta, que como antes ha dicho, no puede ser robado, parece responder de esta irónica forma a la presumible idea de progreso que difunde el soldado. En definitiva, promesa del absurdo al mismo nivel que la abolición del hambre, de la fatiga y de la injusticia.

\section{Figura 3. Fantasía de la máquina de alimentar}

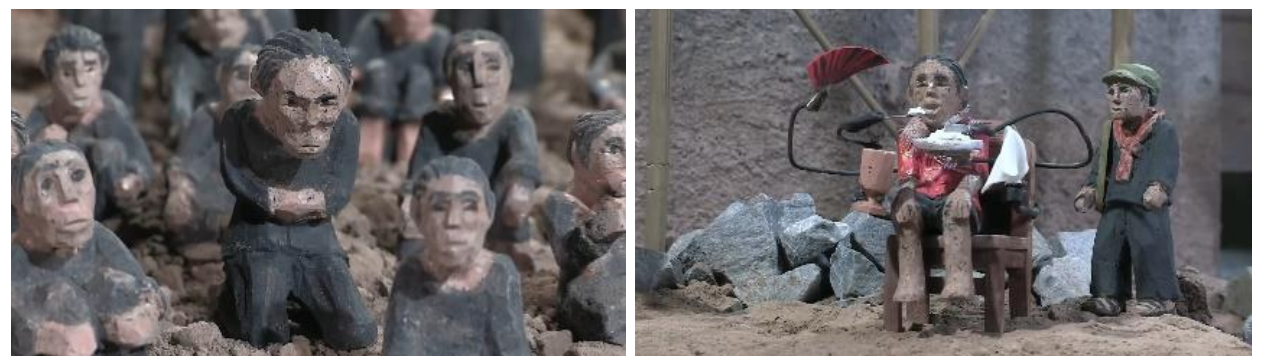

Fuente: fotogramas de La imagen perdida

La fantasiosa construcción del futuro que representa la máquina de alimentar es ampliada con el siguiente diorama, un pequeño ejemplo de la antiutópica sociedad que aspiran a edificar los Jemeres Rojos. Un nuevo travelling revela esta proyección que Panh hace del futuro bajo el régimen revolucionario. Un fondo gris, lleno de nubes, en el que se alza una fortaleza custodiada por soldados armados y frente a la que parten estrechos pavimentos que son recorridos por bicicletas. Banderas rojas por doquier, y entre el arrozal, un coche, símbolo del progreso, es despojado de su función primaria para emplearse su motor hacia fines agrícolas. Una nueva sociedad de contrastes, que se reflejan también en la diferente actitud de los figurines, unos caminando cabizbajos y otros pedalean la bicicleta con una expresión de felicidad.

No obstante, esta sociedad es desmontada completamente en una toma posterior. Una filmación cenital recorre todo el diorama a vista de pájaro desmontando la poca felicidad que se vislumbra mientras se produce un contraste entre el exterior de la fortaleza, verde y ordenado, y el interior, caótico y en obras. En él, los figurines replican las escenas de trabajo que hemos visto en las filmaciones propagandísticas. Sin embargo, la oscuridad del plano, en oposición a la claridad del archivo, así como una mayor cercanía a los sujetos filmados, provocan un sentimiento de tragedia del que estas carecen por sí mismas. Sentimiento que se acrecienta cuando Panh, siguiendo el estilo que ya ha desplegado anteriormente, se acerca a las figuras realizando distintas panorámicas que, con planos cortos, muestran las expresiones deshumanizadas de los figurines. Con una cercanía cada vez mayor el cineasta recupera las imágenes perdidas de todas aquellas víctimas que no han podido dar testimonio de lo acontecido.

La inclusión de la fantasía también sirve para reinterpretar el estado de ánimo del joven Panh. Así, en buena parte de las imágenes de los dioramas el cineasta decide presentarse a sí mismo vestido con una llamativa camisa rosa de lunares amarillos en vez de con el atuendo negro propio de los Jemeres Rojos. Esta caracterización tiene por objeto conferir un sentido emocional a las inanimadas figuras. Así, por ejemplo, una discusión del joven Panh con otros prisioneros sobre la llegada del hombre a la Luna es rápidamente adaptada en forma de sustitución en la que Panh adquiere el mismo ropaje homogéneo que el resto de los figuri- 
nes (fig. 4). Una simple conversación, a través de un sutil juego de cámara con una panorámica vertical, le basta al cineasta para recrear un ambiente de silencio opresor mientras se produce esta transformación personal que descompone a los sujetos simbolizada en el cambio de ropaje. Los recuerdos y la memoria quedan pues enclaustrados en el ámbito privado del pensamiento, existiendo por fuera la total uniformidad, de discurso y de vestimenta. Soluciona de esta manera tan poética Panh una elipsis de la evolución de su actitud. "Ser invisible significaba estar vivo; ser casi un individuo" (Panh, 2013: 80).

\section{Figura 4. Transformaciones del vestuario}
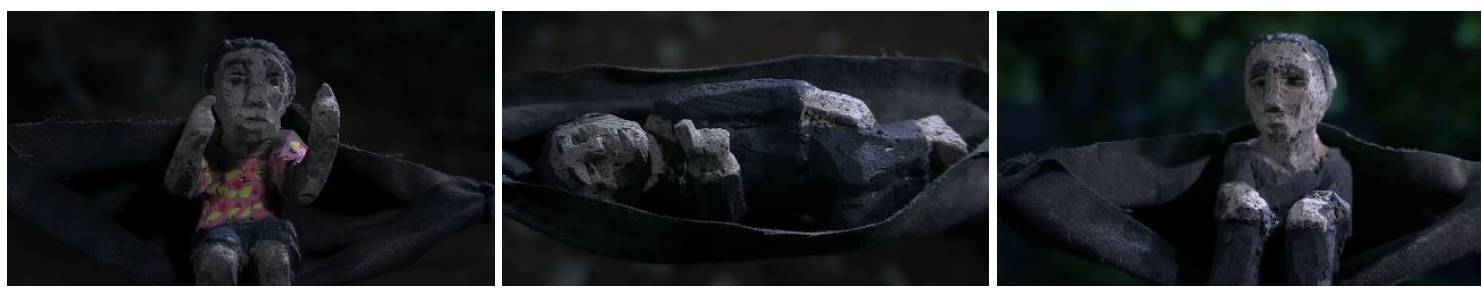

Fuente: fotogramas de La imagen perdida

Más adelante, Panh da cuenta de su rutinario y tortuoso día a día. Un diorama posterior nos lo presenta, junto a otros dos compañeros, transportando distintos troncos a través de la selva. Travellings veloces, algunos los más rápidos que hasta ahora se han presentado, son acompañados por una música que repite una misma cadencia musical. La representación de Panh se encuentra atrapada en un bucle, prisionera del trabajo y del duro modo de vida que le es impuesto. Dificultad para avanzar que se representa en el barro del suelo frente al que el figurín acaba cediendo.

Me gustaría escapar del barro, del hambre,

de mi ropa negra.

Caminar en el agua es un tormento.

Me caigo de cansancio (Panh, 2013b: 39).

Este escape, es solamente posible a posteriori, al compartir la memoria. En donde el acto creativo permite generar una representación que finalmente salve las imposiciones, tal y como se ve con la elección de la camisa rosa como vestimenta preferente. Así, a pesar de reconstruir un trágico pasado, el cine permite al realizador obtener un control sobre sus traumas, siendo así el arte un refugio en su proceso de alivio (Alkan, 2018: 146). Esta sustitución de lo fidedigno de lo real por la representación imaginaria se explicita en la siguiente escena. En ella Panh remite a los momentos en los que un avión atraviesa el cielo bajo el que duramente trabajan los prisioneros. Más allá de los cuestionamientos sobre el poder del avión para testimoniar el crimen, la mano del director hace irrupción en escena para sustituir a la sorprendida versión de sí mismo (en ropaje negro), por una mucho más plácida (vestida con la camisa rosa) (fig. 5). Opera el realizador un cambio inverso al que realizó en la escena nocturna en la que el joven Panh habla de la llegada del hombre a la Luna, restituyendo el orden correcto.

Varios aspectos son interesantes en esta secuencia. Cabe por ejemplo mencionar la inclusión del avión pintado como nuevo plano de la realidad que se introduce en el diorama. Avión, que tal y como el propio Panh confiesa más adelante, existe tan solo en su imaginación, que proyecta su estela en el cielo como una ilusión de que un ente exterior registre pruebas de su dolor. Es además 
en este plano en el que se opera la sustitución en el que el cineasta enuncia la principal imagen que falta, "c'est nous". Frase que coincide con el momento en el que la imagen queda vacía del propio Panh, con una gris figura anónima y desenfocada en el fondo. La justificación de reinstaurar esa imagen que motiva el film apunta a una nueva resignificación de ese pasado doloroso. El avión imaginario salva a Panh, que en el futuro recuerda la ensoñación de esos momentos plasmándolos contemporáneamente en consonancia a sus sentimientos de aquel entonces, la expresión facial tranquila y relajada, y ropa colorida y alegre.

\section{Figura 5. Intervención sobre la fantasía}

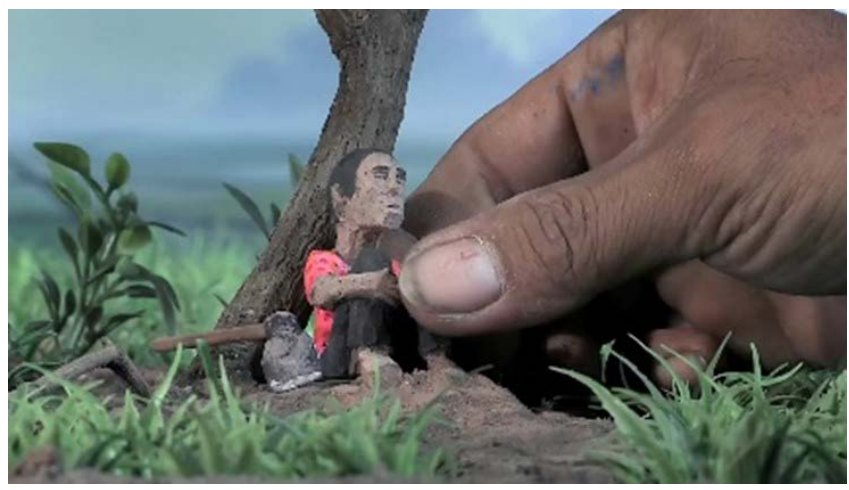

Fuente: fotograma de La imagen perdida

Esta ensoñación vuelve a retrotraerse a los recuerdos de la infancia, que, por su idealización, y en oposición a las imágenes anteriores, se muestran en un sainete alegre y colorido (Phay, 2014: 160). Música rock camboyana de los años sesenta va acompañando el que tal vez sea el montaje de planos más rápido del film, motivado sin duda por el ritmo musical. Con un encadenado que va saltando de una toma a la siguiente sosteniendo el plano apenas un par de segundos, rinde la narración homenaje a una de las figuras, el guitarrista. Hermano del realizador desaparecido el 17 de abril de 1975, día de la evacuación de la ciudad. Sin cortar la música, este pequeño diorama da el salto a imágenes de archivo correspondientes a la película La joie de vivre (Norodom Sihanouk, 1968) (Besse, 2016: 76).

Pequeños cortes, igualmente alegres que muestran a gente bailando o tocando diversos instrumentos propician el despegue del hermano de Panh en la secuencia más onírica de todo el metraje. Un plano cenital sobre el diorama, del que no resta más que una iluminación lateral que resalta las sombras sobre todos los figurines, es usado de fondo para sobreimpresionar la figura del hermano acercándose a la cámara (fig. 6). Se produce así un efecto de elevación del personaje desde el suelo. Esta elevación, dentro de la metáfora que supone, rompe todos los límites, deshaciendo la ilusión de la cuarta pared al mostrar por ejemplo el borde de la mesa donde se sitúa el diorama. Siempre con la música de fondo, planos sucesivos siguen el vuelo del figurín por encima de los habitantes de la ciudad de Phnom Penh. La fantasía continúa al llegar al astro lunar. El Apollo 11 es sustituido por la figura del joven en esta nueva llegada a la Luna en una imagen poética, humorística e incluso psicodélica (Besse, 2016: 51). 
Figura 6. Elevación más allá de la realidad

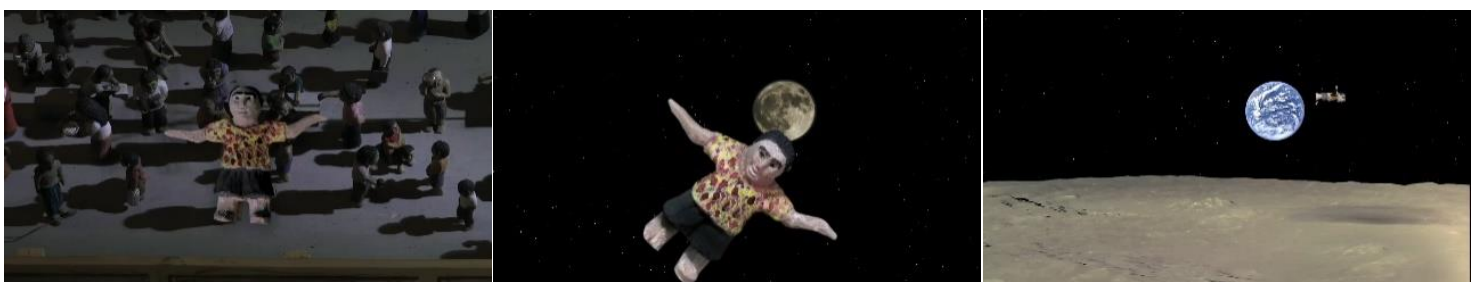

Fuente: fotogramas de La imagen perdida

Igualmente, más adelante Panh vuelve a hacer uso de la fantasía para representar la muerte de sus hermanos. Se genera así una imagen de redención (Sánchez-Biosca, 2016: 66) que no solo honra y redime a sus hermanos, sino que también se impone así mismo - "ya no quiero ver más esta imagen" - un ejercicio que activa un proceso mental que le permita suplantar la imagen de la tragedia por la de la felicidad. Panh busca superar el dolor, aliviar la carga del trauma que tantos años ha tenido con esta imagen que ha representado con los figurines desnutridos y moribundos. Ejemplifica por lo tanto esta escena el poder sanador que el cineasta confiere al séptimo arte. Tras desvanecer en la nada a los figurines de sus hermanos, el montaje los representa, coloridamente vestidos, volando a través del cielo. Esta irrupción de las imágenes fantásticas representa un nuevo posicionamiento del cineasta con respecto a su obra previa, más centrada en el carácter verídico del documental, que será más desarrollado en Exile (2016) en donde las representaciones se abren a crear imágenes eminentemente poéticas.

\section{El testimonio como deber}

Al principio del metraje, antes de pasar a mostrar sus dioramas con figuras como método de reconstrucción de imágenes ausentes, Panh inserta sucesivos cortes grabados con una videocámara en la playa. Grabadas a tan solo unos centímetros del suelo, estas imágenes muestran como las olas del mar se estrellan contra la cámara. El agua golpea contra la lente, magnificando su efecto con el sonido de las olas que por momentos tapa la música ambiental que todavía sigue de fondo. Los cortes entre los distintos planos casi no se intuyen, en lo que es un bucle de distintas olas que golpean una y otra vez sumergiendo el objetivo en el verdoso color que oculta el agua (fig. 142). La cámara vuelve a salir a la superficie antes de volver a ser engullida por el mar. "Sumamente ambigua es la connotación de estos planos: ¿libertad y asociación con esa metáfora universal de la madre y la protección?, ¿anfibología de una explosión que es a la vez ceguera y ahogo?" (Sánchez-Biosca, 2016: 60).

La incógnita de estas imágenes de impotencia y de ansiedad (Duffaud, 2015) es desvelada por Panh en una entrevista. En ella indica que estas primeras tomas pueden ser vistas como una metáfora de la supervivencia, de la lucha, así como una expresión de la necesidad de testimoniar a pesar de la dificultad. "En medio de las caóticas olas que me bañan, tengo que sacar la cabeza del agua. El arte, la creación y el cine dan aliento al alma." (Pahn en Raspiengeas, 2013). O, en otras palabras:

En la película he puesto tres veces esa gran ola que te puede tragar. Intentas levantarte y continuar porque es algo que tienes que hacer: transmitir, no el horror, sino la dignidad y la humanidad de las personas que murieron (Panh en Bradshaw, 2017). 
De esta forma metafórica, el cineasta expone al comienzo de su obra el fundamento principal de la misma, la necesidad y el deber de testimoniar. Así pues, al final de la película, cuando está concluyendo su discurso, Panh repite este corte de las olas del mar. Vuelve la necesidad de testimoniar, asimilada directamente al trauma en un diorama que compone un diván de psiquiatra, cuadro de Freud incluido, con un decorado que restituye simbólicamente el hogar familiar (Besse, 2016: 30). Un figurín de Panh adulto, que se convierte mediante fundido encadenado en el niño que fue, cuenta su historia. Esta constatación del cineasta que se enfrenta a sus memorias en ninguna parte del relato es presentada de forma tan explícita como en estos momentos finales en el diván del psiquiatra (fig. 7). Síntesis de una aproximación personal y autobiográfica que no se había desarrollado en los anteriores films de Panh, más centrados en el discurso de los otros.

Figura 7. Panh recuerda a su familia en el diván

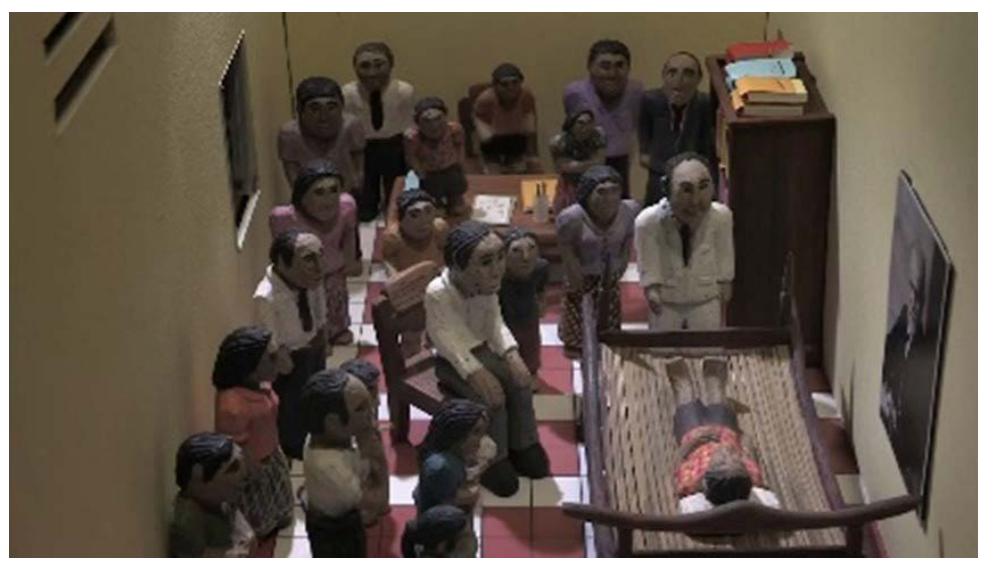

Fuente: fotograma de La imagen perdida

Dejando algo de lado la reconstrucción de imágenes perdidas, la narración adquiere en este último segmento del film un tono de ensayo sobre la propia persona. Progresivamente van apareciendo en la pequeña sala distintas figuras que le representan a él, a su madre o a su padre, en distintos momentos de su infancia. Todos ellos con un atuendo y una expresión que denotan el periodo pre-Jemeres Rojos, le observan tumbado en el diván. Destaca entre estas figuras la del padre vestido de blanco, a cuya construcción asistimos al principio del film, que no llegó a situarse sobre ningún diorama. El íntimo discurso sobre el pasado y todas las pérdidas irreparables de éste da paso al encuentro frustrado con el niño que el cineasta una vez fue.

Ahora es el niño quien me busca.

Lo veo.

Quiere hablar conmigo.

Pero las palabras son difíciles (Panh, 2013b: 65).

Desde el diván del psiquiatra se proyectan directamente sobre la cabeza del cineasta, mediante una sobreimpresión, las imágenes propagandísticas del régimen revolucionario. La película configura en estos fragmentos su contenido traumático caracteri- 
zándose por la "perturbación y fragmentación de los regímenes narrativos y estilísticos de las películas" (Walker, 2005, 19). Se abre entonces una secuencia que antecede a una de las últimas reconstrucciones de la película. Una pequeña fosa en el diorama con una figura dentro representando a un cadáver es cubierta de tierra por sucesivas paletadas. Sin embargo, un rápido fundido encadenado vuelve a traer a la figura a la superficie para volver a ser cubierta. Este gesto se repite en un bucle que se antoja interminable con el fin de reflejar el proceso de trabajo del joven Panh como enterrador. Una cotidianeidad reducida en una labor constante que acaba homogeneizando a todas las víctimas en una sola, la anónima figura que es enterrada una y otra vez y que bien pudiera ser la figura del realizador tal y como indica Olivier Besse (2016: 33) (fig. 8). "Es como si la operación de enterramiento se hubiese vuelto cíclica, eterna, imposible de consumar, pero también, de dejar atrás, originando, por consiguiente, una angustia imprescriptible" (Sánchez-Biosca, 2016: 68).

Mientras se muestran estas imágenes el discurso narrado trata de esgrimir por última vez los fundamentos del film, la necesidad de dar testimonio veraz de lo vivido:

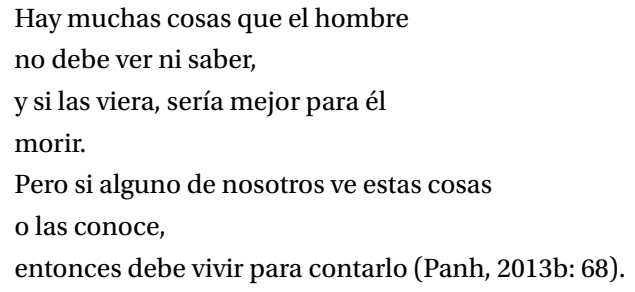

Figura 8. El enterramiento del niño

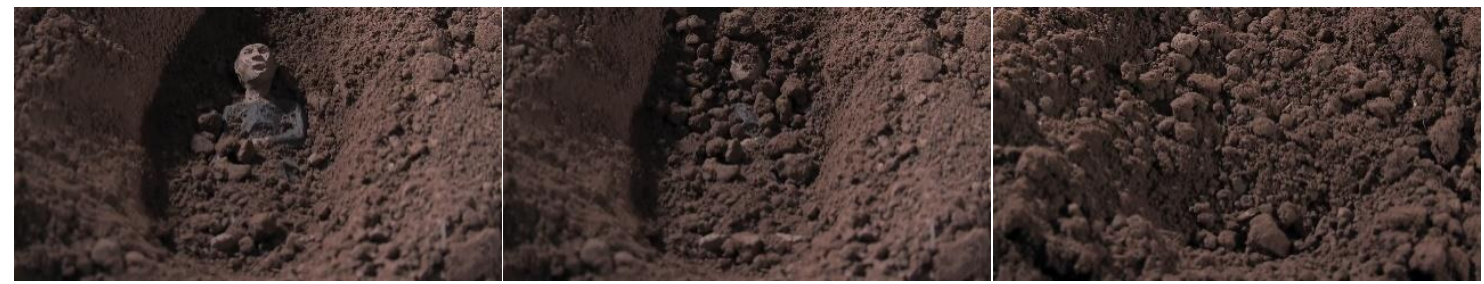

Fuente: fotogramas de La imagen perdida

La constatación de que el narrador sigue vivo, a pesar de la enorme carga traumática que lleva, "Yo soy al que van a matar, o tal vez ya lo han hecho", provoca la elaboración del discurso de su memoria. Una disertación que tiene por finalidad denunciar los crímenes cometidos y homenajear a los muertos. Es en este punto en el que el film es definido como eminentemente político, "una película política debe descubrir lo que ha inventado", aunque frustrado. El propio Panh confiesa haber fracasado en su búsqueda de esa imagen ausente. Es así como surge la creación de imágenes que faltan desde la nada en una operación en la que el cineasta convierte a los receptores del film en herederos encargados de transmitir la memoria, es decir, "El lector-espectador-receptor se convierte en el depositario de una transmisión, de un conocimiento que debe absolutamente devolver, hacer circular a su vez" (Lefeuvre-Déotte, 2016: 5). Así se ofrece esta imagen ausente: 


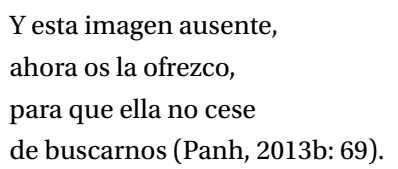

Estos versos finales postulan la necesidad de luchar contra el olvido reemplazando tanto los agujeros negros de la historia como las falsas versiones de la misma. "Una imagen que emerge de la oscuridad es una imagen que emerge de las sombras o de la indistinción y viene a nuestro encuentro" (Didi-Huberman, 2015: 21). Pero ¿a qué imagen de todas se está refiriendo Panh? A la última del film, que vuelve a traer la secuencia de las olas del mar golpeando la cámara. Esta vez en blanco y negro, se suprimen así los colores grises y verdosos que adquiere el agua cuando la lente está completamente sumergida. Se proclama el acto de testimoniar, de buscar una imagen ausente como proceso, aunque el resultado sea insatisfactorio.

Para asentar este mensaje, muestra el director al final de la película, junto a fragmentos pertenecientes a la filmación de sus anteriores trabajos, la construcción de la presente obra. Mientras se desplazan los créditos por la parte izquierda de la pantalla en la parte derecha se presentan imágenes que enseñan todos los artificios que hay detrás del aparato cinematográfico. Y lo que puede descubrirse, condensado en unos pocos planos, es que no hay truco más allá de un largo proceso de investigación, construcción de decorados y figurines, y el hombre... el propio Panh, a solas con su cámara realizando algunos de los travellings y movimientos de cámara que hemos visto a lo largo del metraje. Esta escena de preparación se muestra antes que su propio resultado. La imagen se expande y permite ver al espectador que las figuras de camboyanos asistiendo a un concierto de música en la calle no forman más que parte de una película, dirigida por otras figuras; director, cámara y técnicos, que se encargan de filmar esta puesta en escena. Figuras que reconstruyen las imágenes perdidas de la Camboya prerrevolucionaria. Figuras, ellas también, sumadas a la causa de la búsqueda de la imagen ausente.

\section{Conclusiones}

La imagen perdida parte de la problemática de que, a pesar de existir millones de víctimas, apenas existe documentación gráfica que tenga un carácter probatorio. En este sentido, el film supone un paso más allá en las indagaciones de Panh sobre la representación, sustituyendo las entrevistas y los juegos teatrales por la filmación de unas figuras de arcilla. La apuesta por la animación inanimada pretende pues congelar esos instantes ausentes fijados en la memoria del cineasta. Así, la obra también supone un cambio de posicionamiento de Panh respecto al medio cinematográfico, abandonando el discurso de los otros (víctimas y perpetradores), que se desarrollaba en sus anteriores obras para construir un relato propio.

Basándose en el acto de testimoniar desde la primera persona, Panh compone un texto lírico que va recuperando para la cámara todas aquellas imágenes perdidas del genocidio. Su perspectiva personal como víctima se opone así a las imágenes de los perpetradores, que quedan contextualizadas como parte de la barbarie. Sin embargo, la estructura de la obra avanza de esa búsqueda de imágenes generales del genocidio a la plasmación de vivencias propias. Es así como el cineasta se termina descubriendo a sí mismo enfrentado al trauma sobre su pasado.

La iconografía que buscaba crear una representación realista del pretérito sirve para fantasear con una reconstrucción del pasado, siendo la infancia del director resignificada desde el presente. Panh suplanta las imágenes más duras y violentas por cons- 
trucciones fantasiosas producidas por una mente infantil. De esta manera, el trauma presente con respecto al horror del pasado puede ser reconfigurado de forma positiva -con una colorida camisa que sustituye el uniforme negro de los prisioneros o con el acto de echar a volar como escapatoria- o de forma negativa, con el enterramiento del niño interior. Se genera así una nueva forma de acercamiento documental, que sustituye la veracidad por la construcción poética, que el cineasta desarrollará posteriormente en Exile.

Admitiendo la imposibilidad de recuperar todas las imágenes ausentes, el alegato final del discurso de la voz en off reconfigura el concepto de testimonio como resistencia. Se hace así un llamamiento al espectador para que configure nuevas representaciones contra los agujeros de memoria. La promesa de la imagen ausente se sustituye por el proceso de producción de imágenes. En este sentido, la animación inanimada de Panh funciona como puente entre Los rubios (2004) y Habeas Corpus (2015), plasmando además los fundamentos teóricos sobre los que sostener una ética de representación de memorias traumáticas que pueda ser aplicada a nivel transnacional. Se consolida de esta forma un postulado de representación que puede ser complementado con otras estrategias como el documental animado (Vals con Bashir), el discurso poético (Nostalgia de la luz) o los juegos de interpretación (The Act of Killing) de cara a solventar la carencia de imágenes de archivo traumáticas.

\section{Agradecimientos}

Artículo traducido por Sophie Phillips.

\section{Referencias bibliográficas}

Alkan, D. (2018). De l'image à la narration: la reconstruction mémorielle du génocide cambodgien par Rithy Panh. Litera: Journal of Language, Literature and Culture Studies, vol. 28, no. 2, 131-149.

Assman, J. (1995). Collective Memory and Cultural Identity, New German Critique, no. 65, 125-133.

Becker, E. (1988). Les larmes du Cambodge. Paris: Presses de la Cité.

Besse, O. (2016). Entre théâtre miniature et scène de l'Histoire, les mises en récit de soi dans L'Image manquante de Rithy Panh [trabajo fin de máster 2]. Université Toulouse Jean Jaurés, Toulouse.

Bonnaud, F. y Viviant, A. (21 de octubre, 1998). Quand Jean-Luc Godard nous contait ses Histoire(s) du cinéma. Les Inrockuptibles. Recuperado de https://www.lesinrocks.com/1998/10/21/actualite-cinema/actualite-cinema/ jean-luc-godard-histoires-du-cinema/.

Bradshaw, N. (2017). Memories of murder: Rithy Panh on The Missing Picture. Sight \& Sound. Recuperado de https://www.bfi.org. $\mathrm{uk} /$ news-opinion/sight-sound-magazine/interviews/memories-murder-rithy-panh-missing-picture

Caswell, M. (2014). Archiving the Unspeakable. Silence, Memory, and the Photographic Record in Cambodia. Wisconsin: The University of Wisconsin Press.

Couteau, C. (2000). Rithy Panh. Des territoires en revue, no. 4/5, 20-28.

Didi-Huberman, G. (2004). Imágenes pese a todo: memoria visual del Holocausto. Barcelona: Paidós. 
Didi-Huberman, G. (2015). Sortir du noir. París: Les éditions de minuit.

Duffaud, L. (2015). Rithy Panh: L'image manquante, 2013 -CR de film de lecture. Indomémoires. Recuperado de https://indomemoires.hypotheses.org/17375

Ekchajzer, F. (9 de octubre, 2013). “Rithy Panh vit dans la mort, c'est un rescapé”, Christophe Bataille, écrivain. Télérama. Recuperado de https://www.telerama.fr/ᄀtelevision/rithy-pan-vit-dans-la-mort-c-est-un-rescape-christophe-bataille-ecrivain,103199. php

Ferrer, A. y Sánchez-Biosca, V. (2019). En una selva oscura. Introducción al estudio de los perpetradores. En Ferrer, Anacleto \& Sánchez-Biosca, Vicente (eds.), El infierno de los perpetradores. Imágenes, relatos y conceptos (pp. 13-51). Barcelona: Edicions Bellaterra.

Hamilton, A. (2013). Cambodian Genocide: Ethics and Aesthetics in the Cinema of Rithy Panh. En Bangert Axel, Gordon Robert S. C. \& Saxton Libby (eds.), Holocaust Intersections: Genocide and Visual Culture at the New Millennium (pp. 170-190). Nueva York: Modern Humanities Research Association and Routledge.

Hirsch, M. (2012). La generación de la posmemoria. Escritura y cultura visual después del Holocausto. Madrid: Editorial Carpe Noctem.

Lacapra, D. (2005). Escribir la historia, escribir el trauma. Buenos Aires: Nueva Visión.

Lanzmann, C. (2011). La liebre de la Patagonia. Madrid: Seix Barral.

Lefeuvre-Deotte, M. (2016). Le travail de Rithy Panh: un appareil funéraire. Appareil, articles, 29/06/16, 1-7.

Ly, B. (2017). Se remémorer le 17 avril 1975: à la recherche des images manquantes. En Patrick Nardin, Suppya Hélène Nut \& Soko Phay (eds.), Cambodge: cartographie de la mémoire (pp.167-180). Le Pré-Saint-Gervais: L'Asiathèque.

Margolin, J. L. (1997). Cambodge: au pays du crime déconcertant. En Stéphane Courtois, Nicolas Werth, Jean-Louis Panné, Andrzej Paczkowski, Karel Bartosek \& Jean-Louis Margolin (eds.), Le libre noir du communisme: crimes, terreur et répression (pp. 680-750). París: Robert Laffont-Bouquins.

Martín Sanz, A. (2018). Poética de la violencia en busca de un relato. El drama del refugiado en Exil (2016) de Rithy Panh. Archivos de la Filmoteca, no. 75, 211-224.

Martín Sanz, A. (2018b). Memoria y Trauma de los otros en el cine de Rithy Panh: la trilogía sobre el S-21. IC- Revista Científica de Información y Comunicación, no. 15, 297-327.

Nath, V. (2008). Dans l'enfer de Tuol Sleng: L'inquisition khmere rouge en mots et en tableaux. Paris: Calmann-lévy.

Panh, R. \& Chaumeau, C. (2009). La machine Khemère Rouge. París: Flammarion.

Panh, R. y Bataille, C. (2013). La eliminación. Barcelona: Anagrama.

Panh, R. \& Bataille, C. (2013b). L'image manquante. Paris: Bernard Grasset.

Phay, S. (2014). L'Image manquante de Rithy Panh. Le cinéma comme expérience de l'Histoire. Écrire l'histoire. Histoire, Littérature, Esthétique, 13-14, 157-167. 
Phay, S. (2017). Davy Chou, ou la survivance des images perdues. En Patrick Nardin, Suppya Hélène Nut \& Soko Phay (eds.), Cambodge: cartographie de la mémoire (pp. 181-196). Le Pré-Saint-Gervais: L’Asiathèque.

Raspiengeas, J. C. (8 de octubre, 2013). Rithy Panh: “Comment parler de cette mort en nous?”. La Croix. Recuperado de https:// www.la-croix.com-/Culture/Cinema/Rithy-Panh-Comment-parler-de-cette-mort-en-nous-2013-10-08-1036456

Renard, C. (2018). El sujeto del trauma. Ética \& Cine Journal, vol. 8, no. 2, 73-78.

Rollet, Sylvie (2011). Une éthique du regard. Le cinema face à la Catastrophe, d'Alain Resnais à Rithy Panh. Paris: Hermann Éditions.

Sanchez-Biosca, V. (2015). Le visage fluctuant des victimes. Images de l'affliction au Cambodge (1975-2003). Témoigner entre histoire et mémoire, no. 121, 152-169.

Sánchez-Biosca, V. (2016). El eslabón perdido de las imágenes del genocidio camboyano: En torno a La imagen perdida (Rithy Panh, 2013). Secuencias, vol. 43-44, 51-71.

Sanchez-Biosca, V. (2018). Le chaînon manquant d'un génocide. Autour de L'Image manquante (Rithy Panh, 2013). Savoirs en Prisme, vol. 2, No. 9, 1-24.

Sontag, S. (2010). Ante el dolor de los demás. Barcelona: De bolsillo.

Tavernier, B. (2002). Entretien avec Rithy Panh à propos de S21. Paris: Éditions Montparnasse.

Torchin, L. (2014). Mediation and remediation: La parole filmée in Rithy Panh's The Missing Picture (L'image Manquante). Film Quarterly, vol.68, 32-41.

Walker, J. (2005). Trauma Cinema: Documenting Incest and the Holocaust. Londres y Berkeley: University of California Press.

Williams, P. (2004). Witnessing Genocide: Vigilance and Remembrance at Tuol Sleng and Choeung Ek. Holocaust and Genocide Studies, vol. 18, no. 2, 234-254.

Winston, B. (2012). Ça va de soi: The Visual Representation of Violence in the Holocaust Documentary. En Joram Ted Brink \& Joshua Oppenheimer (eds.), Killer Images: Documentary Film, Memory and the Performance of Violence (pp. 97-119). Londres: Wallflower Press.

Zylberman, L. (2015). Ante la imagen ausente. Exploraciones de la subjetividad en el cine de no ficción. DOC On-line: Revista Digital de Cinema Documentário, no. 17, 100-127. 